\title{
Studies on Qualitative Traits and Effect of Annatto Colour on Beverages of Guava Pulp cv. Lucknow-49
}

\author{
Anuj Kumar ${ }^{1}$, Sanjay Pathak ${ }^{1}$, Atul Yadav², Vimlesh Kumar², \\ Akhilesh Kumar Yadav ${ }^{3}$ and Divya Singh ${ }^{3}$ \\ ${ }^{1}$ Department of Horticulture, College of Agriculture Campus Azamgarh, \\ KVK, Kotwa Azamgarh, \\ ${ }^{2}$ Acharya Narendra Deva University of Agriculture \& Technology, Kumarganj, Ayodhya \\ (U.P.), India \\ ${ }^{3}$ Department of Biochemistry and Biochemical engineering, Sam Higginbottom University of \\ Agriculture, Technology \& Sciences, Prayagraj, U.P. India \\ *Corresponding author
}

\section{A B S T R A C T}

Key w or d s
Lucknow-49, Pulp,
Quality traits and
Beverage

\begin{abstract}
The present study was conducted to know the quantity of chemical characteristics of guava pulp cultivar. Lucknow-49 and sensory evaluation of beverages (RTS and squash) prepared from the pulp. The present study revealed that, total soluble solids $\left(12.80^{\circ} \mathrm{Brix}\right)$, acidity $(0.44 \%)$ vitamin $\mathrm{C},(220.00 \mathrm{mg} / 100 \mathrm{~g}$ pulp $)$, reducing sugars, non- reducing sugar and total sugars of the pulp 6.47 per cent, 3.08 per cent, and 9.55 per cent respectively. Sensory traits revealed that treatment of RTS and squash dyed with annatto colour obtain from $0.8 \mathrm{~g}$ and $2.0 \mathrm{~g}$ seeds/litre respectively, rated "Like Very Much" with highest point as compared to other treatments. Total soluble solids, acidity, reducing sugars and total sugars and non-reducing sugar of annatto colour enriched guava RTS did not change up to 3 month and squash up to 4 month of storage after that increased slightly up to end of experiment. Ascorbic acid in annatto colour enriched guava RTS and squash declined with the progress of storage period.
\end{abstract}

\section{Introduction}

The fruit occupies an important place in the total fruit production of our nation and rank fourth with respect to area and production after banana, mango and citrus. It is commercially cultivated in different states, viz. Uttar Pradesh, Bihar, Punjab, Andhra Pradesh, Karnataka, Gujarat, Maharashtra, West Bengal, Madhya Pradesh and Tamil Nadu.
Total guava production in India is 3,997 thousand MT from268 thousand hectares area (Annonymous, 2018). Uttar Pradesh is leading guava producing state. Allahabad district of Uttar Pradesh has its own benchmark in producing best quality guava in the world.

The fruit has about $83 \%$ moisture and is excellent source of ascorbic acid and pectin but has low energy and protein content. It 
ranks third in vitamin $\mathrm{C}$ content after barbados cherry and aonla. The fruit is rich in minerals like phosphorous, calcium, iron as well as vitamins like niacin, pantothenic acid, thiamine, riboflavin, and vitamin A. It is very useful in preparation of various anti- aging skin care products.

Guava is normally consumed fresh as dessert fruit that is pleasantly sweet and refreshing in flavour. Thalamus and pericarp are the edible portion of this fruit. Fruits maybe utilized to make the products like jam, jelly, RTS, squash, toffees etc. There is great demand of red fleshed guava in the world market for beverages making. In general, cultivars with coloured flesh are poorer in vitamin $\mathrm{C}$ content than the white fleshed ones (Ali et al., 2014).It is a common experience that $20-25 \%$ of the fruit is completely damaged and spoiled before it reaches the consumer. This problem can be overcome by processing of guava fruit into different products like jam, jelly, cheese, canned fruit, RTS, nectar, squash, ice-cream, toffee, leather and candies.

Beverages prepared from white fleshed guava has very good flavour but lacking in attractive colour whereas, pink or red fleshed guava beverages have attractive colour too. Colour found in this group of guava is because of naturally occurring class of organic pigments, called carotenoids. Main constraint in pink or red fleshed guava is their less area of plantation which is not enough tofulfil the demand of guava beverage industries. So on commercial level synthetic colours are used to enhance the eye appeal of guava beverages but nowadays, consumers have become aware of the hazards of synthetic additives in foods and they are looking for foods with natural ingredients.

\section{Materials and Methods}

Total Soluble Solids (\%): For determining the TSS, a drop of sample (pulp/Squash/RTS) is placed on the prism of hand refractometer. Reading was calibrated at $20^{\circ} \mathrm{C}$ with the help of reference table and mean value was expressed as per cent total soluble solids.

Acidity (\%): Dissolve a $5 \mathrm{ml}$ sample in distilled water and maintain volume $50 \mathrm{ml} .5$ $\mathrm{ml}$ aliquot taken and titrated against standard $\mathrm{N} / 10 \mathrm{NaOH}$ solution using phenolphthalein as an internal indicator. The titrated acidity was expressed as gram citric acid per 100gm of sample. (Rangana, 2010)

Acidity $=\frac{\text { Titrate value } \times \text { Normality of } \mathrm{NaOH} \times 64 \times \text { Volume made up }}{\text { Aliquot taken } \times \text { weight of sample taken } \times 1000} \times 100$

\section{Ascorbic Acid (mg/100g)}

$5 \mathrm{ml}$ sample was mixed with $3 \%$ met phosphoric acid $\left(\mathrm{H}_{3} \mathrm{PO}_{4}\right)$ and made up the volume $50 \mathrm{ml}$ with $3 \%\left(\mathrm{H}_{3} \mathrm{PO}_{4}\right) .5 \mathrm{ml}$ aliquot was titrated against 2, 6 dichlorophenol indophenol dye solution as described by A. O. A. C. (2000). The end point was observed by appearance of pink colour, which persisted at least for 15 seconds. (Rangana, 2010).

Ascorbic acid $\left(\frac{\mathrm{mg}}{100 \mathrm{gm}}\right)=\frac{\text { Titrate value } \times \text { Dye factor } \times \text { Volume made up }}{\text { Aliquot taken } \times \text { Weight of sample taken }} \times 100$

\section{Reducing sugars (\%)}

$5 \mathrm{ml}$ or $5 \mathrm{gm}$ sample was taken in $100 \mathrm{ml}$ volumetric flask and volume made up to $100 \mathrm{ml}$ with distilled water. $2 \mathrm{ml}$ aliquot in case of RTS and $1 \mathrm{ml}$ in case of Squash was taken in separate conical flask and $5 \mathrm{ml}$ of each Fehling's solution ' $A$ ' and ' $B$ ' were mixed with aliquot. There after the mixture was heated and titrated against $1 \%$ glucose (Dextrose) solution to the end point of brick colour. A blank sample was also titrated against $1 \%$ glucose (Dextrose) solution. Record both value of titration.

Reducing $\operatorname{sugar}(\%)=\frac{\text { Blank titrate value }- \text { samle titrate value } \times 100}{\text { Aliquet taken } \times \text { weight of samle taken }} \times 100$ 


\section{Total invert sugar}

$5 \mathrm{ml}$ sample was taken and volume made up to $100 \mathrm{ml}$ with distilled water. $5 \mathrm{ml}$ aliquot was taken out from $100 \mathrm{ml}$ aliquot prepared sample and mixed with 3 drops HCL and put for overnight. Next day 2-3 drops phenolphthalein indicator was added and neutralised with $30 \%$ sodium hydroxide solution or tablet. After adding of $5 \mathrm{ml}$ of each Fehling's solution ' $\mathrm{A}$ ' and ' $\mathrm{B}$ ' to neutralise aliquot. Then mixture was titrated against $1 \%$ glucose (Dextrose) Solution in boiling stage using methyl blue as an indicator till appearance of light brick colour indicating point. Record the reading.

Total invert sugar(\%)

$=\frac{(\text { Blank titrate value }- \text { samle titrate value }) \times \text { volume made up } \times 100}{} \times 100$

\section{Non- reducing sugar $(\%)$}

Non-reducing sugar was calculated by deducing the quality of reducing sugars from total invert sugar and multiplied by factor 0.95 . The result was expressed as percent of non- reducing sugar. Non- reducing sugar= Total invert sugar $(\%)$ - Reducing sugar $(\%) \times$ 0.95

\section{Total sugars (\%)}

Sum of reducing sugars and non-reducing sugar expressed in per cent was total sugars.

\section{Results and Discussion}

Chemical composition of guava pulp cultivar Lucknow-49 (Table-1) was recorded in terms of total soluble solids, acidity, reducing sugars, non-reducing sugar and total sugars. Total soluble solids of guava pulp cultivar Lucknow-49 was found $12.80 \%$. The result falls in the range, reported by different scientists which is from 11.00 to $17.01^{\circ}$ Brix (Nale, 2004, Dubey et al., 2011 and Tiwari et al., 2016). Acidity content of guava pulp cultivar Lucknow-49 was recorded 0.44 per cent. Several workers observed acidity in guava pulp cultivar Lucknow-49 varied from0.19-0.47 per cent (Nale, 2004,Nema and Jain, 2007 and Tiwari et al., 2016).In this study ascorbic acid content of guava pulp cultivar Lucknow-49 was found $220.00 \mathrm{mg}$ per 100g pulp however, other scientists have reported $236.00 \mathrm{mg}$ (Nale, 2004), $182.16 \mathrm{mg}$ (Nema and Jain, 2007) and $200.67 \mathrm{mg}$ (Tiwari et al.,2016) ascorbic acid per 100g fruit pulp in guava cultivar Lucknow-49.Reducing sugarsinguava pulp cultivar Lucknow-49 was found6.47per centwhereas, other authors reported 5.10 per cent (Nale, 2004), 7.12 per cent (Dubey et al., 2011) and 3.68 per cent (Kocher et al., 2011).Non-reducing sugar was found 3.08 per cent in guava pulp cultivar Lucknow-49. Non-reducing sugar content observed by other workers was 2.20per cent (Nale, 2004) and 9.12 per cent (Dube et al., 2011) in guava pulp cv. Lucknow-49.

Total sugars $(\%)=$ Reducing sugars $(\%)+$ Non-reducing sugar

Table.1 Chemical characteristics of guava pulp cultivar Lucknow-49

\begin{tabular}{|c|c|c|}
\hline S. No. & Chemical Characters & Value \\
\hline $\mathbf{1 .}$ & T.S.S. $(\%)$ & 12.8 \\
\hline $\mathbf{2 .}$ & Acidity $(\%)$ & 0.44 \\
\hline $\mathbf{3 .}$ & Vitamin C (mg/ $100 \mathrm{~g})$ & 220.00 \\
\hline $\mathbf{4 .}$ & Reducing Sugars $(\%)$ & 6.47 \\
\hline $\mathbf{5 .}$ & Non- reducing Sugar $(\%)$ & 3.08 \\
\hline $\mathbf{6 .}$ & Total Sugars $(\%)$ & 9.55 \\
\hline
\end{tabular}


Table.2 Organoleptic quality of guava RTS, enriched with annatto colour obtained from different amount of seed

\begin{tabular}{|c|c|c|c|}
\hline Treatments & $\begin{array}{c}\text { Amount of annatto } \\
\text { seed(g/litre) }\end{array}$ & \multicolumn{2}{|c|}{ Organoleptic quality } \\
\cline { 3 - 4 } & Nil & 7.7 & Rating \\
\hline $\mathbf{T}_{\mathbf{1}}$ & 0.4 & 7.8 & LM \\
\hline $\mathbf{T}_{\mathbf{2}}$ & 0.8 & 8.2 & LM \\
\hline $\mathbf{T}_{\mathbf{3}}$ & 1.2 & 7.5 & LM \\
\hline $\mathbf{T}_{\mathbf{4}}$ & 1.6 & 6.9 & LM \\
\hline $\mathbf{T}_{\mathbf{5}}$ & & & \\
\hline
\end{tabular}

Total sugar percentage of guava pulp cultivar Lucknow-49 was recorded 9.55 while Nale (2004) and Dubey et al., (2011) reported7.30 and 16.54 per cent total sugar in guava pulp cultivar Lucknow-49, respectively.

The difference in chemical characters in present find and in reported literature may be attributed due to difference in location, orchard management, climatic conditions, fruit maturity, age of the tree and growing season.

The sensory quality factors that are very important for the guava beverages are colour, flavour, appearance and overall acceptability. The organoleptic data (Table -2) on overall ranking of sensory traits which were obtained by addition of scores awarded to different sensory traits revealed that treatment of RTS and squash dyed with annatto colour obtain from $0.8 \mathrm{~g}$ and $2.0 \mathrm{~g}$ seeds/litre respectively, rated "Like Very Much" with highest point as compared to other treatments. Not much work has been done on the application of annatt ocolour on non-dairy products. Satyanarayana et al., (2006) standardised the levels of norbixin concentrations in different fruits and vegetable products as $12.5 \mathrm{mg} / \mathrm{kg}$ for lime squash, $50 \mathrm{mg} / \mathrm{kg}$ for orange squash, 150 $\mathrm{mg} / \mathrm{kg}$ for mixed fruit jam and $50-100 \mathrm{mg} / \mathrm{kg}$ tooty-fruity whereas, Balaswamy et al., (2011) found that water soluble annatto dye sugar powder formulation (WSASF) at the concentration of $5 \mathrm{mg} / \mathrm{kg}$ and $30 \mathrm{mg} / \mathrm{kg}$ were optimum to obtain required colour shades of jilebi and jangri respectively.

\section{References}

A.O.A.C. (2000). Official Method of Analysis. Association of official Analytical Chemists, Washington, D. C. $17^{\text {th }}$ edition.

Ali, D. O. M.; Ahmed, A. R. and Balikir E. B. (2014). Physiological and nutritional value of red and white guava cultivars growth in Sudan. Journal of Agri- Food and Applied Sciences. 2 (2): 27-30.

Anonymous (2018). National Horticulture Board Database, Ministry of Agriculture and Farmers Welfare, Government of India, Gurugram, Haryana, India.

Balaswamy, K; Prabhakar, Rao, PG; Prabhavathy, MB; and Satyanarayana, A. (2011). Application of annatto (Bixaorellana L.) dye formulations in Indian traditional sweetmeats: Jilebi and jangri, Indian journal of Traditional Knowledge.11 (1):103-108.

Dubey, S.; Banafar, R.N.S. and Sahu, G.D. (2011). Effect of storage period on biochemical composition of guava nectar. Environment and Ecology.29(4): 1911- 1917.

Kocher, G.S. and Pooja(2011). Status of wine production from guava (PsidiumguajavaL.): A traditional fruit of India. African Journal of Food. 
Science. 5(16): 851-860.

Nale, S. S. R. (2004). These is development of carbonated guava fruit juice beverage. M.Sc. thesis summited to Mahatma Phule Krishi Vidyapeeth, Rahuri, Maharastra.

Rangana, S. (2010). Analysis and quality control for fruit and vegetable products. Tata McGraw Hill Ltd. New Delhi.

Satyanarayana, A.; Rao, Prabhakara, PG; K,
Balaswamy; Velu, V; and Rao, D.G. (2006). Application of annatto in different fruit and vegetable products. Journal of Food Service, 17: 1-5.

Tiwari, A.; Pal, A.K.; Singh, S.P.; Singh, S.; Singh B. K. and Singh, P. (2016). Evaluation of guava cultivars for quality pulp production Research in Environment and Life Science.9(11): 0974-4908.

\section{How to cite this article:}

Anuj Kumar, Sanjay Pathak, Atul Yadav, Vimlesh Kumar, Akhilesh Kumar Yadav and Divya Singh. 2020. Studies on Qualitative Traits and Effect of Annatto Colour on Beverages of Guava Pulp cv. Lucknow-49. Int.J.Curr.Microbiol.App.Sci. 9(12): 3303-3307. doi: https://doi.org/10.20546/ijcmas.2020.912.393 